\title{
Re-examining the Role of Youths in Independent Political Movements: The Case of Jogja Independent
}

\author{
Desiana Rizka Fimmastuti ${ }^{1}$
}

Received: 28 September 2018 | Accepted: 27 May 2019 | Published: 18 June 2019

\begin{abstract}
This article discusses the involvement of youths in independent political movements since Indonesia's political reform. Political reform became important to be elaborated cause the opening of political space in both political parties and civil society, including for youths. However, this ideal has not been realised, as political parties have been limited by several pathologies and the lack of inclusivity. In the other hand, the establish of independent movements have created alternative spaces for political activity, including for youths. Applying a Bourdieuan perspective, this article examines the habitus and capital evident within such independent movements' political interactions. This article examined the youths in the Jogja Independent Movement (Gerakan Jogja Independent, JOINT), one independent political movement that has been involved in mayoral elections in Yogyakarta City. The exclusivity of political parties has led the movement to gather public support by collecting identity cards and public donations. Although no longer extant, the movement can still be understood as an arena for interactions between openly recruited volunteers and initiators. This study finds that youths have been unable to become agents and voice their own interests. Elitism continues to pose an obstacle to youths' political involvement, as positions of power remain dominated by a small group of elites. Youths, having become involved through open recruitment, have yet to become capable of cross-field movement as they lack the capital of their closed-recruitment peers. At the same time, the academic habitus of these volunteers is incongruent with the political field, leading many youths to leave the movement. Political space being dominated by a small group of elites further limits their available space. The decreasing number of volunteers indicates that JOINT was unable to ensure sustained membership, leading to its ultimate failure.
\end{abstract}

Keywords: youth politics; independent political movement; political space

1 Desiana Rizka Fimmastuti is currently active as a researcher. She was a lecturer at AMIKOM Yogyakarta University in 2018 as well as a research assistant at the Research Centre for Politics and Government (PolGov), Department of Politics and Government, Faculty of Social and Political Sciences, Universitas Gadjah Mada (2016-2018). She received her undergraduate degree from the Department of Politics and Government, Faculty of Social and Political Sciences, Universitas Gadjah Mada, in 2015, and her master's degree in National Security Studies from Universitas Gadjah Mada in 2017. She can be contacted at desianarf1504@ gmail.com/desiana.rizka.f@mail.ugm.ac.id. 


\section{Introduction}

The role of youths in politics is a frequent topic of discussion. Youths are understood as socially active, as driving social changes within the context of specific opportunities and risks in society (Hall, Coffey, and Williamson, 1999). In the current era of political reform in Indonesia, the opening of political space should ideally be used by youths to realise an ideal political system. However, it appears that political parties have yet to offer a substantive space for youths (Meiji, 2015) owing to various pathologies that remain deeply embedded within them. As such, the rise of independent political movements appears to provide an 'oasis' for individuals who otherwise have no opportunity to become involved in politics.

This article examines the involvement of youths in the alternative political space created by the Jogja Independent Movement (Gerakan Jogja Independent, JOINT). The open recruitment mechanism used by this organisation offered a means for youths to become involved in alternative spaces, which wereor at least offered-as free of the pathologies of political parties. However, this movement collapsed following their failure in the Yogyakarta mayoral election. Although this movement was initially highly active, it ultimately collapsed, in part due to its failure to create a solid and loyal 'membership' base-as seen from the limited number of volunteers, who were unable to collect the needed number of identity cards (see Atsari, 2016. Although youths constituted the majority of this movement's members, they did not remain active. The erosion of its membership resulted in JOINT becoming overwhelmed and ultimately collapsing. The author views this collapse as resulting from the dialectical relations between JOINT's actors and structures.

The concept of agency underscores that open political spaces will enable various parties to become agents and contribute politically. In electoral contestations, such as the elections of regional executive leaders in Indonesia, political parties remain 
dominant, even as they are prone to such problems as patronage (Aspinall \& van Klinken, 2011), cartelism (Slater, 2004; Ambardi, 2009), and oligarchy (Robison \& Hadiz, 2004; Winters, 2011). This pathology contributes to other problems, including the expansion of money politics, exclusivity of political parties, and also topdown approaches (Samadhi \& Prasetyo, 2017). As a result of this elitism, youths have become marginalised within political parties. Consequently, political reform Indonesia's democracy has yet to create an ideal political space.

The availability of space for free political expression has stimulated the rise of volunteerism during elections. Organisations such as Risma's Volunteers (Relawan Risma) in Surabaya, Friends of Ahok (Teman Ahok) in Jakarta, and Jogja Independent movement (Jogja Independent JOINT) in Yogyakarta have attempted to optimally use the spaces made available by political reform. These movements may be perceived as alternative political spaces with its own stories and dynamics.

For example, the Friends of Ahok movement in Jakarta was established based on two points: opposition to the dominance of political parties and the effects of populism (Sihidi, 2017). Supporters of Basuki Tjahaja Purnama, popularly known as Ahok, desired the candidate's contestation of the regional elections because they saw him as having already performed well. Working to collect the identity cards of potential voters, they sought to ensure Ahok could run without the support of a political party. Ahok's own personality was seen as an important factor uniting these supporters in their mobilisation activities.

JOINT, another volunteer movement, had a different pattern than Friends of Ahok. JOINT was a movement that could be understood as stemming from anti-party sentiments, or more specifically dissatisfaction with the behaviours of political parties (Pamungkas, 2012) in Yogyakarta. Disappointment in political parties led activists and artists to create alternative spaces for their political activities, including movements that were not centred on 
individual candidates. JOINT declared itself to be a 'movement of citizens' interests', which sought to gain access to the political structure and used open recruitment mechanisms to highlight its inclusivity. Through this mechanism, JOINT sought to create opportunities for the general public to become involved in politics at the local level.

Ideally, such a space should be used by youths to improve their social and political conditions. The limited space for them within political parties was a powerful force driving youths to contribute to the movement. In this article, the author characterises youths as members of an academic community with a specific habitus; this is done out of recognition that $68 \%$ of all volunteers were youths from academic backgrounds. As such, through their involvement in JOINT they went from the field of academics to trying their hands at the field of politics.

These youths' efforts to try their hands in a new field is interesting. Criticism of existing political processes is necessary to ensure that youths have the opportunity to take part in inclusive political spaces, or even democratic revolutions. Some evidence indicates that youths are capable of becoming actors in the transformation of political systems, as seen in the Philippines in 1980, Nepal in 2006, Serbia in 2000, Georgia in 2003, Ukraine in 2004, and Kyrgyzstan in 2005 (Kuzio, 2006). In Indonesia, the Youth Pledge of 1928, the Rengasdengklok incident, the rise of the generation of ' 60 , and the political reform of 1998 offers further evidence that youths have positioned themselves within the political system and played a significant role.

A review of extant studies of youths and politics has driven this study to fill existing knowledge gaps, as it does not only look at youths as agents capable of bringing important change to their surroundings. Previous research into youths' participations in elections (Hidayatullah, 2015), youths' promotion of political participation (Fuad, 2015), as well as other topics have focused on youths' activities as agents. Youths have been seen as actors capable 
of transforming the situations around them through their own potential, i.e. becoming agents of change.

This article does not only examine youth movements as part of agency. Rather, it seeks to understand the relations between the youths involved within the JOINT movement during the Yogyakarta Mayoral Election. The failure of this movement may reflect the failed dialectics of the political movement arena, as well as the inability to create a strong "membership". This article applies Bourdieuan theory to examine youth involvement in JOINT, simultaneously analysing the connection between habitus, capital, and field. The writer attempts to show two main indicators. First, as in political parties, the movement did not offer significant political space for youths' contributions. Second, the habitus of the youths was closely linked to their political activities. These youths went from an academic community into a political one, indicating the fluidity and flexibility of their political behaviour (Trijono \& Djalong, 2011). The process they experienced was not an easy one, as they attempted to penetrate a new arena and actualise themselves within the JOINT movement. Within this movement they faced other groups with their own habitus, specifically the Committee Team and the Selectorate Team.

\section{Concepts of Youth And Political Space}

This study offers an exploration of youths as political subjects, who have their own choices and preferences in responding to the social and political dynamics. The increased openness of political space has enabled youths to take a role in promoting change, while at the same time struggling within the organisational structure. This study examines the use of a structure-agency approach to understand the youths within a new space: an independent political movement. In this case, the erosion of JOINT's membership is caused not only by members' failure to integrate within the new political space, but also JOINT's failure to create a sense of "membership" and thereby 
ensure youths' continued involvement.

First of all, it is necessary to elaborate a definition of youth as a concept. There are at least two main categories that may be used to understand youths: youths as objects and as subjects. In many studies, youths have often been narrated as objects (Aini, 2011), including through the demographic categorisation of youths as persons between the ages of 20 and 30 (Seo, 2017) or 16 and 30 (Fimmastuti, Pramusinto \& Soerjo, 2018). Such definitions, however, generally failed to consider the traits that distinguish youths from other age groups. As such, another theoretical preposition is to position youths as subjects who actively respond to social changes. In a socio-political context, Olaiya (2014) writes that youths tend to be reactive when dealing with deviancies in their surroundings (Olaiya, 2014). Their reactivity leads to youths being considered subversive and radical, especially in societies that remain adultcentric (Aini, 2011). Youths are seen as lacking the experience and reckless in responding to the situation around them.

Both of these definitions imply that youths cannot be identified based solely on their age, but also on other aspects that characterise them as a social group. Definitions based on age are insufficient to accurately understand youths as agents within specific socio-political structures. For Bourdieu (1978, in Azca 2011), the concept of youth has transformed over time, in accordance with the social, political, and moral values of the era. As such, youths cannot be separated from the social constructs that emerge over time. For example, the term 'millennial' or 'Generation Y' is often linked to persons born between 1981 and 1997 (Frey, 2018). They are characterised as expressive, explorative, open to various means of accessing information, preferring everything instant (Wahana, 2015), and even individualistic and spontaneous in their political activities (Hidayat, 2018). These characteristics shaped their activities and their behaviours when they become involved in social and political spaces in order to actualise their interest.

Although youths have significant potential as actors, in 
practice it is not so easy to dealing with political structure. As subjects, youths are often at the forefront of social change and as such face both significant risks and opportunities (Hall, Coffey, and Williamson, 1999). As agents, they are located within specific social structures and interact with other groups that have their own interests. For example, in Indonesia, the adult-centric character of society remains a significant challenge for the youths who seek to become involved in politics.

Youths, as unique subjects, have often been studied within the context of politics. The perspectives of youths as agents tend to dominate youth studies, which tend to position youths as actors with the ability to take a stand within a specific social context. Korzenevica, for example, has elaborated on the youths' use of political party patronage in post-conflict Nepal. These youths have been able to become involved in post-conflict development programmes (Korzenevica, 2016). Similarly, Kuzio (2006) has highlighted the role of youths in democratic revolution and regime change in Serbia, Georgia, and Ukraine. In these countries, youths dominated civil society and established coalitions to achieve their goals. Furthermore, Fuad (2015) has investigated the role of youth volunteers in promoting electoral participation in Indonesia. In such studies, the 'agency' perspective remains strong, with youths being positioned as actors with the capacity and potential to bring about change (i.e. to become agents of change).

This research does not only examine youths as agents, but also elaborates upon the structures around them. A study by Seo (2017) has explored the demographic and political factors in Korea that have influenced youths' low levels of involvement in elections. The majority of voters in the 2012 Korean presidential election were older, and as such the youths have felt that their voices would not be heard. This study sought to elaborate upon the structures surrounding the Korean youths, and by doing so understand how these structures limit their agency.

Studies of JOINT as a political movement have been 
undertaken by several researchers. These studies have explored such topics as the activities of the candidates and volunteers (Atsari, 2016) as well as the candidacies process by the movement (Imawan, 2017). Both of these studies have identified this movement as having strong elitist tendencies. The current study is intended to complement these earlier projects, focusing on how youths struggled within the movement and ultimately decided to leave it and the political space; such decisions contributed to the failure of the movement.

This study combines two common understandings of youths, defining them based on their age group and the traits that characterise them. Youths, in this study, are persons from an academic background who were positioned as agents capable of entering political space following the beginning of political reform. Here, the writer will explore the dialectics between youths as agents of change and the political structures of the movement. In its explorations, this article refers to the writings of Pierre Bourdieu (1992 in Adib 2012), particularly the concepts of habitus, field, and the interactions between them.

Youths' decision to end their involvement in the independent political movement may be seen as a result of them coming from a different field than the political field in which they had become involved. Habitus, meanwhile, is the mental structure within individual actors that is shaped through the internalisation of their experiences in the past. It is this habitus that underlies every individual's perception, understanding, and appreciation of social practices. Meanwhile, the field is more relational than structural. It is an arena in which various habitus can meet and interact, as well as an arena in which access to resources can be contested through the use of capital. The position of an agent depends heavily on the capital available to him or her, be it economic, social, cultural, or symbolic. As such, an agent's command of capital and habitus will help determine whether an agent can endure within a social structure. Such a command will also determine who can gain power and permanence within the arena (Adib, 2012) 


\section{The Ebb and Flow of Youths in Indonesian Politics: A Review From The Pre-Independence to The Post-Reform Eras}

The involvement of youths in politics is not a new political discourse in Indonesia. It can be traced from the pre-independence era through the post-reform era. A brief review of this topic indicates that youths' involvement in politics cannot be separated from the socio-political contexts. Youths' involvement in politics began with the emergence of the concept of Indonesia as a nation. The activism of STOVIA students, as well as the Youth Pledge of 1928, may be seen as evidence of youths' understanding of and involvement in politics. Colonialism and the suffering of the Indonesian people led to the rise of youth movements intended to spread the spirit of nationalism among local peoples (Pertiwi, 2013). The dynamic political development of the youths transformed them into agents who fought for the independence of the Indonesian nation. They were the ones who urged the political elites to proclaim Indonesia's independence, as well as the ones who worked towards developing a spirit of nationalism (Kroef, 1972; Suryadinata, 1978; Anderson, 1988). Youths' abilities as subjects capable of agenda setting cannot be separated from the political structures of the time. The growing sense of nationalism as well as the presence of an oppressive colonial government stimulated them, leading them to seek independence in various ways, including diplomatic and underground channels.

In the early years of Indonesian independence, the presence of youths was an important consideration. The political structures, which were still very fluid, made it possible for a wide range of political actors. Under Soekarno, youths were a formational element of the National Council (Yulianto, 2002). The political space available to them also stimulated their criticism of the Soekarno regime, as seen in the rise of the Generation of ' 66 , their voicing of their demands through the Three Demands of the People (Tiga Tuntutan Rakyat), and ultimately the fall of the regime. Feeling that they had successfully voiced the demands and views of the 
people, these youths viewed the new regime-the New Order, under Soeharto-optimistically (Argenti, 2016). This optimism, however, did not last long, as the new regime soon enacted policies that 'closed' the political space for ensuring economic and political stability. This again resulted in resistance from youths, such as in 1974. Such views were, however, unable to have a significant effect owing to the influence and power of the ruling regime. The "Dosomuko" political system enacted by the New Order regime was effective in controlling elements of society-including youths - that could potentially disturb the stability of the regime (Zubir, 2000). The system used by the regime with various instruments to achieve its interests. For example, the National Committee of Indonesian Youths (Komite Nasional Pemuda Indonesia, KNPI), ostensibly a vehicle for youths' aspirations, was used as a means of controlling them, only enabling political participation that furthered the interests and policies of the regime (Rukminijati, Rais, \& Winarno, 1995). It can be seen that Indonesia's political structures under the New Order limited youths' political participation. This included in political parties, whose recruitment mechanisms did not focus on age categories, but looked more at regional, ethnic, and religious background (Usman, 1996). Under the control of the New Order regime, youths lacked the space to become political agents (Hadiz, 2002).

The fall of the New Order has been seen as stemming from accumulated public disappointment in the regime, and youths are believed to have played an important role in this process. Changes in Indonesia's political system were seen as stimulating youths' optimism and driving them to contribute and more involved into politics. The liberties introduced through political reform enabled youth movements to become more divergent and have their own visions and missions (Robison \& Hadiz, 2004). However, even in this condition, the links between youths themselves remained unclear; individuals remained united by their political, religious, and ethnic backgrounds (Trijono \& Djalong, 2011). This can be seen 
from, for example, the Indonesian Muslim Students' Movement (Gerakan Muslim Islam Indonesia, GMII) working together with the United Development Party (Partai Persatuan Pembangunan, PPP) to influence government policies, as well as the shared ideologies of the Action Unit of Indonesian Muslim Students (Kesatuan Aksi Mahasiswa Muslim Indonesia, KAMMI) and the Prosperous Justice Party (Partai Keadilan Sejahtera, PKS) (see Daliyoto, 2013; Nugrahani, 2015). As such, it may be noted that the social tendencies under the New Order have been maintained even until the present day (Minza, Wahid, Zaky, \& Shabrina, 2017). At the same time, political parties continued to provide limited space to youths, as the party elites remained structurally powerful. Meiji (2015), for example, showed that youths' low position in party hierarchies resulted in them being relegated to the task of simply gathering votes and support. Youths, therefore, have experienced symbolic violence even as they have attempted to persevere and reaffirm their positions.

This short historical review has that youths' capabilities as subjects have depended on their contexts and contemporary political structures. Although independent political movements may be seen as providing alternative political spaces, they remain influenced by contemporary structural conditions and the availability of political spaces to the youths.

\section{Optimism in New Political Spaces: The Case of Jogja Independent Movement (JOINT) in Yogyakarta}

The dynamics of youths' involvement in politics cannot be separated from the contexts in which they are situated. A review of the history of youths' involvement in Indonesian politics has shown that they have had significant agency in promoting change. However, Meiji (2015) has shown that, within political parties, youths are heavily dependent and cannot act as agents. They face significant elitism, both at the hands of their seniors and at the hands of capital 
holders.

The rise of independent political movements in the postreform era is an interesting phenomenon. Dissatisfaction with political parties stimulated anti-party sentiments (Pamungkas, 2012). Independent movements, thus, emerged as new spaces for people to become involved in politics without any political party involvement. In Burlington, the United States, Bernie Sanders rose to the mayorship through an independent 'rainbow coalition' of Black organisations, farmers, and peace groups (Minot, 1989). Aside from his own personal charisma, Sanders won the hearts of voters through his slogan "we, as citizens". The issues of his constituents had not been addressed by political parties, which had focused only on their own ideological concerns and thus been unable to address the real issues experienced by society.

In Indonesia, the beginning of political reform provided significant momentum for opening broad political spaces following 32 years of authoritarian rule. This opportunity was seized by a range of actors who sought to become politically involved either through political parties or independent movements. In Yogyakarta, political parties remained a significant force, as can be seen by their loyal support at the district level.

In the past few years, several controversial decisions have been made by elected mayors, including the issuance of permits for supermarkets and the widespread construction of hotels. The ties between political parties and specific mayoral candidates were seen as one reason for such controversial policies. As such, several activists decided to initiate their own independent movements so that they could back candidates who were free of party interests.

The Jogja Independent Movement (Jogja Independent, JOINT) was established by seven people from different backgrounds, including artists, academics, advertisers, consultants, and activists. Emphasising such concepts as citizen independence, this movement sought to draw media and social attention through dignified and moral educational and political activities. It shared its vision and 
mission through various media to draw the attention of the public, including the attention of youths.

The exclusivity of political parties led JOINT to enact an open recruitment policy, enabling anybody to become a volunteer or candidate. As such, the movement sought to avoid mainstream channels, instead working to optimise social media use, introduce their candidates, and collect public donations (Imawan, 2017). Furthermore, this movement sought to prove its legitimacy by receiving support from local and national elites such as Busyro Moqoddas, Zainal Arifin Mochtar, and Herry Zudianto.

The lack of human resources (volunteers) is interesting to examine within the context of new spaces other than political movements. The number of youths was quite high; a total of $68 \%$ (or 50 volunteers) were youths. The small number of older volunteers may be attributed to their being used to working with campaign teams and receiving formal funding and support (Imawan, 2017). Nonetheless, it must be recognised that these youths were ultimately marginalised.

In terms of background, the young volunteers at JOINT were primarily students and other persons from an academic background. Initially, they viewed this movement as unique, as being capable of offering an alternative and cleaner means of practicing politics (Fimmastuti, 2017). Their motives were similarly diverse, from the idealist to the pragmatic. Common motives included the desire to gain experience, to complete research assignments, or to support specific candidates; some even became involved after having been mobilised by their lecturers.

The motive was clear: to bring about improvement and, more significantly, to show that youths could really contribute because we had the capacity. We had clear visions and missions for the future, and we didn't have pasts that could be subject of doubt. I also wanted to prove that youths needn't believe that they are too young to try, too young to get involved in practical activities, too young to bring about significant change. No. The youths 
could!" (EYR, personal communication, February 16, 2017). ${ }^{2}$

EYR's idealism was one factor that drove her, at the age of 25 , to become the youngest candidate in the Yogyakarta mayoral election. JOINT was perceived as inclusive, as accommodating anybody who desired to become involved in politics. To support further analysis, this article recognises two categories of volunteer involved in the movement. First are the general volunteers, who did not have any links to specific candidates. Generally, these volunteers were students who were searching for experience, completing university assignments, etc.; as such, their motives ranged from the pragmatic to the idealist. Second were the campaign volunteers, who generally worked towards supporting specific individuals as the official mayoral candidates were selected. In elections, all candidates are required to have a team supporting them and proving public support. Given this more practical motivation, campaign volunteers tended to have different tendencies. Often, they would stop volunteering after their candidates failed. Both types of volunteer influenced the dynamics of JOINT.

In terms of candidates, at least four individuals identified themselves as 'youths' or 'young people' in their taglines: Adrie Primera Nuary, Emmy Yuniarti Rusadi, Hambar Riyadi, and Titok Hariyanto (JOINT, 2016). The following are the taglines used by these candidates:

"I'm a young person who cares for and is willing to work together with all elements of Yogyakarta society to maintain and develop the city. As such, I prepared the slogan "Makarya Kuwi Bebarengan" (Making Masterpieces

Interview with EYR, the youngest person (age 25) to register as a mayoral candidate with JOINT.

Original: "Motivasinya jelas untuk melakukan perbaikan dan yang lebih besar lagi adalah menunjukkan bahwa sebenarnya anak muda bisa karena kita sebenarnya punya kapabilitas. Kita punya visi misi yang jauh lebih clear ke depan, dan kita nggak punya masa lalu yang bisa diragukan gitu. Saya juga ingin membuktikan bahwa sebenarnya anak muda itu tidak perlu percaya bahwa terlalu muda untuk mencoba, terlalu muda untuk masuk ke ranah praktis, terlalu muda untuk mengubah sesuatu yang besar, ndak juga ya. Anak muda bisa!" 
Together). My vision was to bring about an exemplary and aspirative government, for the sake a of humanitarian and competitive Yogyakarta City $^{3}$ - Adrie Primera Nuary, SH

I'm a representation of the Indonesian youth who are willing to dedicate themselves to social welfare through innovation. The City of Yogyakarta must become a city with a good quality of life, based in culture, optimised technology, and sustained development ${ }^{4}$ - Emmy Yuniarti Rusadi, ST, M.Eng

I'm a young person willing to work politically to build up the City of

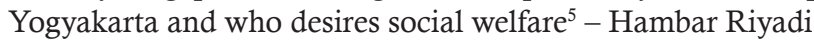

I'm a progressive and visionary young person who seeks to promote Yogyakarta City as an inspiration for change in Indonesia, relying on active participation and social empowerment, as well as responsive and accountable governance ${ }^{6}-$ Titok Hariyanto

These various taglines were used as part of these candidates' identities and were socialised in various forums. In general, they were optimistic about the future and sought to actively promote change in the region. These candidates were evaluated based on the key performance indicators formulated by a team of panellists.

Open candidacy gave youths a new space to become involved in regional leadership. They sought to abandon the traditional channels, which have been dominated by the influence of political parties. Nonetheless, it must be recognised that their approach

3 Original: "Saya anak muda yang peduli dan ingin bekerja bersama seluruh elemen masyarakat Kota Yogyakarta guna merawat dan memajukan kotanya, maka dari itu saya mengusung jargon "Makarya Kuwi Bebarengan". Visi saya adalah mewujudkan pemerintahan yang aspiratif dan berketeladanan, demi terciptanya Kota Yogyakarta yang berkemanusiaan dan berdaya saing tinggi."

4 Original: Saya adalah representasi pemuda Indonesia yang berani setia pada kemashlahatan sosial melalui inovasi. Kota Yogyakarta harus bisa menjadi kota yang Layak Huni Berbasis Budaya, Pengoptimalan Teknologi, dan Pembangunan Berkelanjutan”.

5 Original: Saya adalah kaum muda yang siap berjuang secara politik untuk membangun Kota Jogja dan ingin terwujudnya masyarakat yang sejahtera.

6 Original: Saya adalah anak muda yang progresif dan visioner dan ingin mendorong terwujudnya Kota Yogyakarta sebagai inspirasi perubahan Indonesia dengan bertumpu pada partisipasi aktif dan kekuatan masyarakat serta tata kelola pemerintahan yang tanggap dan bertanggungjawab. 
posed a significant challenge to them, as they needed to struggle to gain public attention as independents despite political parties' domination of the political arena in Yogyakarta. As such, the limited number of available volunteers was a significant challenge for JOINT.

In choosing potential candidates for mayor and deputy mayor, JOINT sought to provide alternative candidacies that forefronted public involvement through convention. As such, JOINT's team of initiators created a convention team using a closed recruitment scheme. This team consisted of local and national elites, including Busyro Muqoddas (legal practitioner), Bambang Eka Cahya Widodo (academic), Herry Zudianto (former mayor of Yogyakarta), Yustina Neni (artist), and Suparman Marzuki (legal practitioner). It is this team that was entrusted with forming a selection team within the movement (Atsari, 2016). Based on their knowledge and capacity, a Team of Nine was formed, with members including Busyro Moqoddas, Suparman Marzuki, Zainal Arifin Mochtar, Bobi Setiawan, Budi Wahyuni, Achmad Nurmandi, Herry Zudianto, ST Sunardi, Robby Kusumaharta, and Edi Suadi Hamid (JOINT, 2016).

The JOINT convention involved various processes, but ultimately failed to fulfil the administrative criteria for candidacy. It failed to back up Garin Nugroho and Rommy Heryanto, as it was unable to collect the 26,347 identity cards necessary to prove public support (as required by Article 10, Paragraph 1b of General Elections Commission Regulation No. 5 of 2016). JOINT was unable to prove the necessary public support owing to its lack of volunteers. The requirement to collect more than twenty thousand identity cards was a serious obstacle, as only 73 volunteers were involved. Owing to their limited time and funding, these volunteers were only able to collect 4,027 identity cards (Hasanudin, 2016). According to Atsari (2016), their weaknesses included their lack of deep-rooted strategies, failure to accommodate democracy within the movement, as well as limited financial and human resources 
(Atsari, 2016).

The factors that caused JOINT to collapse, well you can guess. You can look at the resources, and then its limited ability to build networks within civil society. There were also too few volunteers. Ideally, to be sustainable, there should have been 800 or more, or about 900 , volunteers. But there were only about 100 or so. And of those, only 15 were active. We all were busy with our own activities, not surprising given that most of the volunteers were university students and lecturers. And at the time, it was in the lead-up to the end-of-term exams, as well as the community service programmes... and there weren't enough financial resources either. I mean, Garin's a film director. If he were to spend all his money, that wouldn't be possible. The cost of taking out newspaper ads is quite high. And in organising volunteers, the strategies used were also lacking (Informant, personal communication, February 17, 2017). ${ }^{7}$

In reviews conducted with youth volunteers, it was apparent that they viewed resources as having significantly influenced their ability to collect identity cards. The ever-decreasing number of volunteers united in JOINT simply could not collect the identity cards necessary to prove public support for the movement.

\section{The Limited Opportunities to Youths Within the Political Spaces of Independent Movements}

JOINT's ultimate failure may be attributed in part to its lack of human resources, i.e. volunteers (Atsari, 2016). JOINT's volunteers were predominantly (68\%) youths, and those involved in the organisation may be understood as actors who made use of alternative political spaces. They were motivated by and interested in the clean practice of politics, but it is also important to note that

\footnotetext{
Interview with a JOINT volunteer who also examined JOINT as part of an undergraduate thesis.

Original: "Faktor-faktor yang membuat JOINT gagal bisa ditebaklah ya. Bisa dilihat dari sumber dana, sama settlenya dia membangun jaringan ke masyarakat kan kurang. Relawan juga kurang. Kalau hitungan-hitungan relawan amannya kan seharusnya jumlahnya 800 lebih atau 900 kurang. Ternyata relawannya itu 100an lebih. Dan yang aktif itu, hanya sekitar 15 orang. Kita juga punya kesibukan masing-masing, apalagi relawan kebanyakan mahasiswa dan dosen. Apalagi waktu itu kan pas semester genap, menjelang UAS, menjelang orang-orang KKN. Terus sumber dana kurang. Maksudnya Garin kan sutradara kalau dia keluar uang semua kan nggak bisa, buat iklan di Koran itu besar. Terus untuk pengorganisasian relawan, strategi relawan juga sangat kurang."
} 
they were mostly from an academic background.

JOINT members may be divided into two major categories, namely volunteers who became involved through open recruitment (general candidates, general volunteers, and campaign volunteers) and those who became involved through closed recruitment (team of initiators, convention team, and selectorate team). Each group had its own tendencies, as can be seen below.

Table 1: Analysis of Differing Groups in JOINT

\begin{tabular}{|c|l|l|l|}
\hline No & $\begin{array}{l}\text { Differentiating } \\
\text { Aspect }\end{array}$ & Closed Recruitment & Open Recruitment \\
\hline 1 & Group & $\begin{array}{l}\text { Team of Initiators/Team } \\
\text { of Seven; Convention } \\
\text { Team/Team of Five; } \\
\text { Selectorate Team/Team } \\
\text { of Nine. }\end{array}$ & $\begin{array}{l}\text { Volunteers, campaign } \\
\text { volunteers, and } \\
\text { candidates }\end{array}$ \\
\hline 2 & Background & $\begin{array}{l}\text { Professionals, including } \\
\text { local and national elites }\end{array}$ & Mostly Academics \\
\hline 3 & Motivation & Idealism & $\begin{array}{l}\text { Idealism and } \\
\text { pragmatism; mostly } \\
\text { mobilised university } \\
\text { students }\end{array}$ \\
\hline 4 & Capital & $\begin{array}{l}\text { Economic, cultural, } \\
\text { social, and symbolic }\end{array}$ & $\begin{array}{l}\text { Economic, cultural, and } \\
\text { social }\end{array}$ \\
\hline
\end{tabular}

Source: Analysis by researcher

From this table, it can be seen that four characteristics distinguished persons recruited through closed and open mechanisms. The youths who became involved in the movement through open recruitment were students, including those mobilised by their lecturers and those who supported specific candidates. Meanwhile, closed recruitment was used for the initiators and selectors, many of whom were activists, artists, entrepreneurs, or experienced local 
and national political actors. The open recruitment mechanism was capable of creating space and opportunities for volunteers and candidates. In this context, individuals recruited through closed and open mechanisms became involved in politics. Both had their own approaches. The core team had a strategic space, as it consisted of the pioneers and designers of the movement. It was these individuals who had prepared the movement, and they were the ones who mobilised the volunteers to collect identity cards, mobilise support, and introduce JOINT to the people.

... when I first joined, there was Mrs Neny, and people really underscored that JOINT was independent. We weren't affiliated with any political party. We wanted to help build Jogja. That was our introduction, and then everything else was more technical. Because we were youths, it was more about things like collecting votes, the strategies available. And then we were challenged to get something like 1,000 voters or introduce JOINT to 1,000 people. In the end, we created a Twitter account, used a JOINT hashtag, \#JogjaRaDidol. And then, for Emmy's team, we also made an official Facebook account: 'Bayangke Jogja' (Imagine Jogja). Updated information there, then went to the field. We went to some different areas like Mergangsan. Went to the neighbourhood leaders, said that Emmy was running. That Mr Hambar was running. Basically, introduced JOINT to various villages (Informant, personal communication, March 31, 2017) ${ }^{8}$

Although the number of youths involved in JOINT was significant, this did not in and of itself enable the youths to become agents of change capable of influencing JOINT and its movements. From the beginning, JOINT's various strategies and support mechanisms had been designed by a team recruited by the team of initiators. The youths were mere objects in the movement, receiving

Interview with a volunteer who supported the campaign of one JOINT candidate.

Original: “. . . Pas pertama kali gabung, kan ada Bu Neny banyak dikasih tahu bahwa JOINT ini intinya adalah independen. Kita tidak berafiliasi dengan parpol, intinya pengen bantuin memajukan Jogja. Itu sebagai pengantar, selebihnya lebih bersifat teknis. Karena kita anak muda jadi lebih kayak gimana caranya mendapatkan suara anak muda kota, strateginya apa. Terus kita dikasih challenge buat mendapatkan kirakira 1000 pemilih atau 1000 orang untuk mengenal JOINT. Akhirnya kita bikinlah twitter, hashtag JOINT, \#JogjaRaDidol. Terus sebagai timnya Emmy, kita juga membuat Official Account Facebook 'Bayangke Jogja'. Update info, habis itu ikut ke lapangan. Ke beberapa kampung kayak Mergangsan. Dulu ke Pak RT gitu, buat ngasih tahu kalau Emmy nyalon. Mas Hambar nyalon. Intinya perkenalan ke beberapa kampung." 
information and guidance during capacity building forums. It is through these forums that JOINT provided guidance and information to its volunteers. However, it was limited to technical matters, giving the impression that youths were simply positioned only as supporters of the movement. They were tasked with further developing strategies that had already been designed by another team, and as such there was minimal space for dialogue (Atsari, 2016).

Although initially volunteers appeared to be fighting for clean and democratic politics, in reality they only handled technical and administrative duties. They approached JOINT with their own hopes and interests, but were unable to become agents and bring about substantive change. They entered an exclusive space in which they were only allowed to handle administrative activities and seek public support. Youth volunteers were trapped between their subordination within the structure and the interests they sought to realise.

JOINT's campaign teams and volunteers had shared interests. They were both involved in a new political space, and both emphasised openness and new opportunities. However, they had different tendencies. The campaign teams and volunteers enjoyed a relatively open space, wherein they could formulate specific issues and platforms for their candidates. They focused on preparing candidates for an election and acted based on their pragmatic interests, seeking to support candidates who could still potentially be elected. As such, the tendencies and directions of the movement depended heavily on their interests.

This condition differed significantly from that of ordinary volunteers. JOINT's busy schedule, as well as its limited number of volunteers, had its implications for the duties undertaken by youths in the movement. Volunteers were directed towards technical matters, such as managing the secretariat, helping candidates handle administration, and organising events (Atsari, 2016).

The limited availability of political space for youths was not 
only evident in their being limited to technical and administrative duties; the structure being closed to their contributions further limited their opportunities. Some studies have shown that independent political movements have been closed to youths. Atsari (2016), for example, has shown that political spaces within JOINT were not open to youths, as indicated by the limited space and coordination between the elites and volunteers within the organisation. This created a gap between the two elements of the group.

This broad gap, in turn, implied limited emotional bonds between volunteers and the movement. Furthermore, the youths volunteering with JOINT were predominantly from an academic background, and were therefore involved in such activities as examinations, community service programmes, and other organisational activities. As such, there was no loyalty to the organisation.

\section{The Dominance of Elites Among Independent Candidates and The Marginalisation of Youths}

Describing itself as 'a movement of citizens' interests', JOINT sought to present an alternative political space that was free of the interests of political parties. With limited time for preparations, the movement had to prepare its candidates as well as fulfil specific administrative requirements. As such, the organisation of volunteers and selection of credible candidates were undertaken simultaneously. The different groups within JOINT were involved in the mayoral election in different ways.

The youths who became involved in JOINT through open recruitment mechanisms were driven by a range of motives, from the mobilisation of their lecturers to the backing of specific candidates. As common among millennials, these young volunteers were explorative and willing to try new things (Wahana, 2015); this included in JOINT, which sought to offer a new way of doing politics. However, despite their optimism, they were only involved 
in a limited capacity. They were unable to make optimal use of the spaces available within the independent movement because of the influence of elitism both in the selection of candidates and in the setting of movement agendas.

First, elitism in candidate selection. To distinguish itself from political parties, which have been characterised as oligarchic and elitist, this movement sought to recruit candidates through open mechanisms and selection processes: public selection (stage 1), preconvention, public selection (stage 2), and the JOINT convention. Some 41 people took registration forms, but only 15 ultimately registered themselves as potential candidates. During this process, the core JOINT team was dominant. Their knowledge, capacities, and networks gave them more power than the youth volunteers in the movement. These elites were activists and professionals with a solid capital base, and as such were able to dominate the movement.

The influence of these elites is evidenced in the results of the selection process. Only the open recruitment, public selection (Stage 1), and public selection (Stage 2) were open to the public. Public participation was limited in the pre-convention stage, in which involved only the Team of Nine. It was this team that evaluated the visions, missions, and programmes of the candidates, and it was this team that decided upon five candidates to be discussed during the convention stage. Similarly, the convention stage of the selection process was not particularly open. Although voting was conducted, the committee did not formally announce the number of votes received by candidates. JOINT only announced that it would propose Garin Nugroho and Rommy Heryanto as its candidates (Atsari, 2016). A study by Imawan (2017) has argued that elitism was strongly evident and influential in the centralistic selection mechanism used.

Second, the movement's direction was determined predominantly by the core JOINT team. JOINT had established a team that was tasked with preparing strategies for achieving the movement's goals. This team was dominated by a group of elites, 
who came both from the team of initiators and the selectorate team. Youths who had become involved with the movement through its open recruitment mechanism were asked to prepare events, socialise the movement, and gather public support. However, they lacked the space to influence the policies and grand strategies of the movement. They were only used to handle technical and administrative matters, which ultimately affected the number of volunteers. Only fifteen volunteers remained with the movement until its ultimate end.

The drastic decrease in the number of volunteers can be seen as their response to the movement. Initially, these youths migrated from the field of academics to the field of politics, which encompasses different tendencies and concepts. Furthermore, these volunteers were given limited space for growth, a fact that went against the public demand for spaces for dialogue and the socialisation and dissemination of ideas (Cruz, 2016). Volunteers perceived JOINT as not only unable to provide them with political space, but also as being a vehicle for elitism, both in candidacy mechanisms (Imawan, 2017; Atsari, 2016) and in agenda-setting. The habitus of volunteers distinguished them from other activists, and informed their motivations; volunteers could be motivated by support for specific candidates, the need to fulfil their lecturers' expectations, etc.

These volunteers did not feel a sense of belonging in the movement. This was not only caused by the elitist candidacy mechanisms, but also the fact that the spaces and opportunities granted to them failed to meet expectations. The volunteers could not become agents of change, contributing to movement's agendasetting, as the political structure remained closed to them. The Team of Five, Team of Seven, and Team of Nine were all produced through closed recruitment mechanisms, and included persons who had more capital than the volunteers recruited through open mechanisms. The analysis presented in Table 1 above shows that youths lacked the symbolic capital (prestige) of the elite movement members. The elites in the organisation had their own track records, 
reputations, and experiences, which provided them with a strong basis for becoming dominant in JOINT. Youths' relative lack of capital, thus, weakened their legitimacy and ability to contribute to agenda-setting. As such, it may be understood that volunteers lacked political agency.

The gap between the political arena and the volunteers' habitus further influenced their decision to leave the group. These youths, who were quite pragmatic in their decisions, over time left the movement as they felt that it did not 'belong to them'. Some of them left JOINT when their own interests were not realised, such as when their candidates failed the selection process.

But there were others who had their own needs, like assignments. They'd come because they needed to do so to get money. That was possible. But them, they weren't all that active. Maybe they were thinking, "this is not my way". Maybe they were bored or had other priorities. I tried to get them interested, "let's go"... but volunteers, well we don't get paid. So it's not surprising that some of them decided to leave. (Informant, personal communication, April 1, 2017) ${ }^{9}$

Wasn't as active as Miss Emmy there. See, I wasn't a hypocrite. People would be passionate if they had their own interests, like in supporting Emmy. The other candidates were also the same. So after Miss Emmy became one of the final three and the others were pushed aside, and they weren't visible during the final debate trying to narrow the field from three to two candidates. And there was no contract to bind them. People just said, well they're volunteers. They hoped that volunteers would continue to help JOINT promote itself and collect identity cards even if their preferred candidate didn't win... but there was nothing written saying "You must do this" or "You must do that." In my opinion, if there's nothing in black and white, well then it's not binding. Everyone has their own activities... so after Emmy left, I didn't have any more direct contact with JOINT. (Informant, personal communication, March 30, 2017) ${ }^{10}$

9 Interview with a JOINT volunteer entrusted with managing the JOINT website and other technical matters.

Original: Tapi ada juga karena kebutuhan misal seperti kayak tugas tadi. Mereka datang karena mereka memang butuh untuk mendapatkan data. Itu kan something possible. Tapi untuk mereka yang enggak aktif itu mungkin karena mereka ada di titik : this is not my way, udah bosen atau mereka punya prioritas yang lain. Ya aku sempat merasa ayolah, maklumlah, namanya relawan kita nggak dibayar. Jadi hal yang wajarlah mereka memutuskan untuk bertahan atau pergi.

10 Interview with a JOINT campaign volunteer who supported one of JOINT's mayoral candidates.

Original: Nggak seaktif waktu Mbak Emmy disitu. Soalnya nggak munafik karena setiap 
The marginalisation of youth volunteers cannot be separated from their own personal interests, which highlights their lack of ownership of the movement. If volunteers had had a sense of ownership, it would have been possible for them to remain involved even in the face of examinations, community service programmes, etc. Similarly, campaign volunteers sought only to promote the selection of their own candidates. As such, it is not surprising that the volunteers backing certain candidates ended their involvement in JOINT after their candidates were not selected. Similarly, most volunteers in JOINT were involved only in technical and administrative duties, lacking the space to influence movement policies and agendas. The minimal availability of funding also provided a reason for leaving the movement.

Based on these findings, it may be stated that JOINT lacked inclusivity. Open recruitment was seen as a means of mitigating the elitism and exclusivity that had characterised political parties. However, this mechanism was unable to guarantee broad public access. Open participation was made possible for certain things, but the selection of mayoral and deputy mayoral candidates remained in the hands of the elites. This exclusivity was apparent in the limitation of volunteers' ability to determine the direction of the movement, which was instead dominated solely by the team of initiators and the selectorate team. Both of these groups played a central role in organising the movement, and as such left little substantive space for the youths. Facing such a reality, many volunteers - especially the young ones - abandoned their initial hopes. They ultimately did not continue their involvement with the movement, as they lacked

orang akan semangat jika ada kepentingan ya kayak ndukung Mbak Emmy. Calon yang lain juga gitu. Jadi setelah Mbak Emmy masuk 3 besar dan yang lain tersisih, juga nggak keliatan waktu final debat 3 calon menuju 2 calon. Dan juga tidak ada keterikatan kontraknya. Cuma dibilangin, ini relawan, diharapkan relawan masih membantu JOINT mempromosikan dan mengumpulkan KTP meskipun calon yang diusung ngga menanggitu. Tapi tidak ada secara tertulis saya akan begini-begini, tidak ada secara materai. Kalau menurutku nggak ada hitam di atas putih ya ngga terlalu mengikat gitu. Karena setiap orang punya kesibukan masing-masing. Jadi setelah Mba Emmy keluar, kontakan sama JOINT langsung enggak. 
a sense of belonging and ownership. A movement that should have provided new spaces for the public ultimately became exclusionary under the influence of significant elite biases.

It is interesting to reflect upon the activities of JOINT volunteers within the context of actors and alternative political spaces in Indonesia. Volunteers, in this case the students and other academics who joined JOINT through open recruitment, had a different habitus than the elites. They were members of the millennial generation and most familiar with the academic field. Their decision to leave the movement was closely linked to their own characteristics as millennials, i.e. individualistic and spontaneous (Hidayat, 2018). The youths, who were initially optimistic, ended up focusing on their own affairs as they felt no sense of belonging or ownership. Furthermore, JOINT was controlled by a small group of elites who enjoyed a power that was rooted in their knowledge and prestige. The youths, meanwhile, lacked such capital and as such could not actualise themselves. They may thus be seen as having failed to consolidate themselves within their interactions with the elites in JOINT.

\section{Conclusion}

From the analysis above, it may be concluded that youths were unable to become agents and voice their interests in aspirations within the independent political movement JOINT. They experienced the same problems they would in Indonesia's political parties, namely elitism and limited opportunities. Meiji (2015) has previously shown how, in Indonesia's political parties since political reform, youths have only been used as a means of mobilising voters because parties forefront seniority. This research has found a similar situation, with power being wielded by the team of initiators and selectors while youths were only given technical and administrative duties. The problem of elitism remained strong, and as such the youths could not easily function as active subjects within the political space. 
As a movement, JOINT may be seen as an arena in which various groups interacted based on their individual habitus. The Bourdieuan perspective used in this paper, thus, can critically explain why youths failed to cross different fields. As mentioned above, JOINT relied on both open and closed recruitment mechanisms, which reached people with different characteristics and capitals. Persons recruited through closed mechanisms had stronger capital bases, as realised through their knowledge and economic capacity, and thus could readily dominate JOINT as an arena and set its agendas as a movement. Meanwhile, the youths recruited through open mechanisms had limited capital and a different habitus, and as such they could not become strong forces within the JOINT movement.

Based on this analysis, at least two main points may be made regarding youths and independent political movements. First, youths in such movements are entrusted solely with technical and administrative duties. They don't have the necessary spaces to make decisions because agenda-setting activities are centralised. The limited openness of political spaces through which youths could achieve their interests led to a lack of a sense of belonging and ownership, which in turn led youths to choose to leave the movement. Second, the problem of elitism was apparent in the candidate recruitment process. Although the use of open recruitment mechanisms made political spaces open to all, the selectorate team continued to dominate the candidate selection process. Such a situation is problematic, given that movements seek to forefront public inclusivity.

The findings of this study have illustrated the position of youths in alternative political spaces since political reform began in Indonesia in 1998. Previous studies have been able to position youths as agents who can become active agents and manifest an ideal socio-political framework (see Hidayatullah, 2015; Fuad, 2015). This is what has led to the phrase 'agent of change' being commonly used in the prologues of many youth studies. This study 
has sought to fill a gap in the literature by also considering the structure within the political movement. It has shown that youths have been unable to assert themselves and their aspirations. The incongruency between their academic habitus and the political field led them to leave the group. This was exacerbated by their lack of capital, and as a result they were unable to control JOINT and its political spaces. Furthermore, the decreasing number of volunteers involved in JOINT indicates that the movement was unable to create a strong and loyal membership.

The case of youths' political involvement in JOINT during the 2017 mayoral election in Yogyakarta illustrates how political spaces remain closed by elitism. Elitism implies a limitation of space, which in turn indicates an inability to create members who are loyal to the movement and have a sense of ownership. Reflecting on this reality, the author concludes that youths have yet to occupy an optimal position in post-reform politics. Their habitus and capital remains limited in the political spaces made available by independent political movements such as JOINT. Twenty years of political reform has created space for political parties and interest groups to participate in voicing certain aspirations. However, such involvement is only effective where individuals have the correct habitus and sufficient capital to enter and control political spaces. 


\section{References}

Adib, M. (2012). Agen dan struktur dalam pandangan Pierre Bourdieu. Biokultur, 1(2), 91-110.

Aini, N. (2011). Politik identitas dan gerakan perdamaian pemuda. In M. N. Azca, S.A. Margono, \& L. Wildan, Pemuda pasca Orba: Potret kontemporer pemuda Indonesia (pp. 109-126). Yogyakarta: Yousure.

Azca, M.N. (2011). Pemuda (i) dan radikalisme agama. In M. N. Azca, S.A. Margono \& L. Wildan, Pemuda pasca Orba: Potret kontemporer pemuda Indonesia (pp. 69-88). Yogyakarta: Yousure.

Ambardi, K. (2009). Mengungkap politik kartel: Studi tentang sistem kepartaian di Indonesia era reformasi. Jakarta: Gramedia and LSI.

Anderson, B. (1988). Revoloesi pemoeda: Pendudukan Jepang dan perlawanan di Jawa, 1944-1946. Jakarta: Pustaka Sinar Harapan.

Argenti, G. (2016). Gerakan sosial di Indonesia: Studi kasus gerakan mahasiswa tahun 1974. Jurnal Politikom Indonesiana, 1(1), 1-19.

Aspinall, E., \& van Klinken, G. (2011). The State and illegality in Indonesia. Leiden: KITLV Press.

Atsari, A. (2016). Politik relawan: Kandidasi calon perseorangan di Jogja Independent (JOINT). Yogyakarta: Universitas Muhammadiyah Yogyakarta.

Cruz, E. (2016). Young immigrants' association and the future latino leadership in the U.S.: Dreamers' social capital and political engagement. Norteamérica, 11(2), 165-191.

Daliyoto, S. (2013). Perubahan pilihan politik masyarakat pada pemilihan umum legislatif (Studi kasus perubahan pilihan politik masyarakat kota Yogyakarta atas lima partai utama perolehan suara nasional Pemilu 2004 dan Pemilu 2009. Yogyakarta: Universitas Muhammadiyah Yogyakarta.

Fimmastuti, D. (2017). Persepsi pemuda tentang gerakan Jogja Independent (Joint) dalam pelaksanaan Pilwalkot Kota Yogyakarta tahun 2017 dan implikasinya terhadap ketahanan politik pemuda. (Unpublished master thesis), Universitas Gadjah Mada

Fimmastuti, D.R., Pramusinto, A., \& Soerjo, D. (2018). Persepsi dan Tindakan Politik Pemuda Terhadap Gerakan Jogja Independent (JOINT) dalam Pelaksanaan Pilwalkot Kota Yogyakarta Tahun 2017 dan Implikasinya Terhadap Ketahanan Politik Pemuda (Studi pada Relawan Jogja Independent (JOINT) di Kota Yogyakarta. Jurnal Ketahanan Nasional, 24 (1), 94-116. 
Frey, W.H. (2018). The millennial generation: A demographic bridge to America's diverse future, Metropolitan Policy Program at Brookings.

Fuad, Z. M. (2015). Peran pemuda relawan demokrasi dalam meningkatkan partisipasi politik masyarakat pada Pemilihan Umum Legislatif tahun 2014 dan implikasinya terhadap ketahanan politik wilayah (Studi pada relawan demokrasi Banyumas, Jawa Tengah) (Unpublished master thesis), Universitas Gadjah Mada, Indonesia.

Hadiz, V. (2002). The Indonesian labor movement: Resurgent or constrained? Southeast Asian Affairs, 130-142.

Hall, T., Coffey, A., \& Williamson, H. (1999). Self, space and place: Youth identities and citizenship. British Journal of Sociology of Education, 20(4), 501-513.

Hasanudin, U. (2016). JOINT mundur dari kontestan Pilwalkot, apa alasannya? Harian Jogja. Retrieved from http://m.harianjogja. $\mathrm{com} / \mathrm{baca} / 2016 / 07 / 21 /$ pilkada-jogja-joint-mundur-darikontestan-pilwalkot-apa-alasannya-738921.

Hidayatullah, B.A. (2015). Partisipasi pemuda dalam Pemilihan Umum 2014 dan implikasinya terhadap ketahanan politik wilayah pondok pesantren (Studi di Yayasan Pondok Pesantren Ali Maksum, Krapyak Kulon, Desa Panggungharjo, Kecamatan Sewon, Kabupaten Bantul, Propinsi Daerah Istimewa) (Unpublished master thesis), Universitas Gadjah Mada, Indonesia.

Hidayat, A.N. (2018), Beda cara generasi milenial dalam politik. Kompas. Retrieved from https://nasional.kompas.com/ $\mathrm{read} / 2018 / 09 / 17 / 19090001 /$ beda-cara-generasi-milenial-dalampolitik.

Imawan, A. (2017). Mengungkap proses kandidasi calon independen Komunitas Relawan Jogja Independent menjelang pemilihan Walikota Yogyakarta tahun 2017. Yogyakarta: Universitas Gadjah Mada.

JOINT. (2016). ACARA: Tim 10 Yang Menjadi Panelis Konvensi. Jogja Independent. Retrieved 3 January 2017 from http:// jogjaindependent2017.com/acara-tim-10-yang-menjadi-paneliskonvensi/.

JOINT. (2016). KANDIDAT: Bakal Calon Walikota JOINT. Jogja Independent. Retrieved 3 January 2017 from http:// jogjaindependent2017.com/kandidat.

Korzenevica, M. (2016). Young people navigating political engagement through post-war instability and mobility: A case from rural Nepal. Geoforum, 74, 19-28. 
Kroef, J. (1972). Indonesian nationalism reconsidered. Pacific Affairs, 45(1), 42-59.

Kuzio, T. (2006). Civil society, youth and societal mobilization in democratic revolutions. Communist and Post-Communist Studies, 39(3), 365-386.

Meiji, N. (2015). Pemuda dan partai politik (Studi mengenai latar belakang dan strategi anak muda untuk bertahan serta membangun karir politik di dalam Partai PDIP dan PKB pada Pemilu Legislatif 2014). Yogyakarta: Universitas Gadjah Mada.

Minot, S. (1989). American eye: What makes Bernie run? The North American Review, 274(4), 8-13.

Minza, W. M., Wahid, M., Zaky, M., \& Shabrina, Z. R. (2017). Youth movements and the politics of recognition and redistribution. In E. Hiariej, \& K. Stokke, Politics of Citizenship in Indonesia (pp. 271304). Jakarta: Yayasan Pustaka Obor Indonesia.

Nugrahani, S. (2015). Dinamika relasi organisasi kolateral independen dan partai politik: Relasi gerakan mahasiswa Islam Indonesia (GMII) dan Partai Persatuan Pembangunan (PPP). Yogyakarta: Universitas Gadjah Mada.

Olaiya, T. (2014). Youth and ethnic movements and their impacts on party politics in ECOWAS Member States. Sage Open, 4(1),1-12.

Pamungkas, S. (2012). Partai politik: Teori dan praktek di Indonesia. Yogyakarta: Institute for Democracy and Welfarism.

Pertiwi, C. (2013). Peranan pemuda dalam pergerakan nasional Indonesia, 1908-1920. Jember, East Java: Universitas Jember.

Robison, R., \& Hadiz, V. (2004). Reorganising power in Indonesia: The politics of oligarchy in an age of markets. London: Routledge Curzon.

Rukminijati, T., Rais, A., \& Winarno, B. (1995). Peranan Komite Nasional Pemuda Indonesia (KNPI) dalam pembangunan politik: Studi kasus di Jawa Barat. Jurnal Berkala Penelitian Pasca Sarjana Universitas Gadjah Mada, 8, 325-338.

Samadhi, W. P., \& Prasetyo, W. (2017). Gerakan pro demokrasi mengambang tanpa strategi yang berakar. Prisma, 3(1), 67-82.

Seo, Y. (2017). Democracy in the ageing society: Quest for political equilibrium between generations. Futures, 85, 42-57.

Sihidi, I.T. (2017). Ekspresi volunteerism politik studi Teman Ahok di Pilkada DKI Jakarta 2017 (Unpublished master thesis), Universitas Gadjah Mada, Indonesia.

Slater, D. (2004). Indonesia's accountability trap: Party cartels and 
presidential power after democratic transition. Indonesia, 78, 6192.

Suryadinata, L. (1978). Indonesian nationalism and the pre-war youth movement: A re-examination. Journal of Southeast Asian Studies, 9(1), 99-114.

Trijono, L., \& Djalong, F. F. (2011). Pemuda sebagai agensi politik problem dan tantangan dalam periode pasca Orde Baru. In N. Azca, Pemuda pasca Orba: Potret kontemporer pemuda Indonesia (pp. 21-36). Yogyakarta: Yousure UGM.

Usman, S. (1996). Pemuda, ulama dan Pemilu: Tinjauan sosiologi politik. Jurnal Ketahanan Nasional, 1(1).

Wahana, H.D., (2015). Pengaruh nilai-nilai budaya generasi millennial dan budaya sekolah terhadap ketahanan individu (Studi di SMA negeri 39 Cijantung Jakarta). Jurnal Ketahanan Nasional, 21(1), 1422.

Winters, J. (2011). Oligarchy. New York: Cambridge University Press.

Yulianto, A. (2002). Hubungan sipil militer di Indonesia pasca Orba. Jakarta: Rajawali Press.

Zubir, Z. A. (2000). Dari NKK/BKK ke era Reformasi: Studi tentang gerakan mahasiswa di Sumatera Barat 1978-1999. Padang: Universitas Andalas. 